\title{
Some Developing Region Tests Of The Heckscher-Ohlin Theory
}

\author{
MARTin T. KaTZMAN*
}

\begin{abstract}
The Heckscher-Ohlin theory of interregional trade is tested as an explanation of regional patterns of specialization in Brazil. With the Northeast defined as the labor-abundant region and São Paulo as the capital-abundant region, there seemed to be no relationship between sectoral capital-labor ratios and regional specialization, contrary to hypothesis. On the other hand, the Northeast specializes in unskilled-labor intensive industries, and São Paulo, skilled-labor interior industries, conforming to hypothesis. In agriculture, the pattern of state specialization in some commercial crops seems predictable by the relative land-labor endowments.
\end{abstract}

The Heckscher-Ohlin theory was conceived as a general model of interregional and international trade and specialization (Ohlin, 1933). On the assumptions of identical production functions and tastes but differing factor endowments among regions, the theory implies that a region will specialize in those commodities which are intensive in its abundant factor of production. In this essay, we test whether the Heckscher-Ohlin theory can predict the regional patterns of manufacturing and agricultural specialization in Brazil.

Regional tests of the Heckscher-Ohlin theory have been proposed to obviate some of the confounding problems of international tests. It is more likely that different regions of the same country than different countries will have identical production functions; a narrow range of factor endowments, which diminishes the likelihood of factor reversals; identical demand patterns; and freedom of trade.

A major difficulty in performing conclusive regional tests of the HeckscherOhlin theorem revolves around a priori identification of factor endowments. In Moroney and Walker's (1966) pathbreaking article, capital was assumed to be scarce and labor abundant in the American South, which makes sense in light of relative factor prices. When the static results refute the prediction that the South specializes in labor-intensive industries, the abundance of natural resources in that region was invoked ad hoc to explain the observed industry mix. Since resource-intensive industries also tend to be capital-intensive (Kravis, 1956; Vanek, 1963), Southern specialization in these industries has been accompanied

\footnotetext{
*Associate Professor of City and Regional Planning, Harvard University, Cambridge, Massachusetts.
} 
by capital inflows (Romans 1965), which violate the assumption of exogenous endowments. Estle's (1967) extension of Moroney and Walker's analysis to New England assumes that capital is scarce and labor abundant in this region on the basis of aggregate capital-labor ratios in manufacturing. This interpretation of these ratios is difficult to reconcile with New England's historical role as a capital exporter and a capital market offering the lowest interest rates in the nation (Davis, 1965; Schaaf, 1966; Romans, 1965).

In this essay, the manufacturing tests focus upon two regions whose factor endowments are unequivocal; São Paulo state and the Northeast, which contain about one-fifth and one-third of the national population, respectively. The agricultural tests deal with twenty states, whose factor endowments are less clearly specified.

\section{Manufacturing}

While São Paulo has been the focus of Brazilian industrialization during this century, the Northeast has remained until recently, a relatively stagnant, low-income, agricultural region (Schuh, 1971). As an index of the national average, bank deposits per capita are roughly 202 in São Paulo and 14 in the Northeast. The index of wages of operatives about 114 in São Paulo and 56 in the Northeast. Furthermore, interest rates on deposits have been lower in the major financial center of São Paulo than in the two largest banking centers of the Northeast. ${ }^{1}$ These indicators jibe well with the common view of São Paulo as capital-abundant and the Northeast as labor-abundant regions.

For each region separately, the 1960 location quotients of twenty manufacturing sectors are correlated with their respective capital-labor ratios. These correlations are repeated for 1940 and for changes in quotients between 1940 and 1960, for thirteen sectors. By hypothesis, the correlation should be positive for São Paulo and negative for the Northeast. In fact, for both regions, the correlations in both 1940 and 1960 are insignificantly different from zero; moreover, changes in the quotients during the period, 1940-1960, are insignificantly correlated with the capital-labor ratios (Table 1, Panel A).

These results imply that manufacturers are unresponsive to the relative unskilled labor and capital costs in the two regions, choosing activities on other grounds. A closer inspection of interregional wage differentials may explain the paradox, for the salary indices cited above are misleading indicators of either private or social costs of unskilled labor. The manufacturing firms for which the above data were collected are subject to a stringent minimum wage law. In 1960, the official minimum wage in São Paulo was about thirty-three percent more than that in the biggest Northeastern industrial centers. ${ }^{2}$ Minimum wage in both regions are higher than the private opportunity cost of labor, which is roughly proportional to the agricultural wage. In the late 1960's, the minimum wage in São Paulo was about fifty percent higher than the agricultural wage, while in the Northeast, the minimum wage was 140 percent higher. ${ }^{3}$ As is predictable from Todaro (1969) and Harris and Todaro (1970), unemployment rates 


\section{TABLE 1}

\section{PANK-ORDER CORRELATIONS BETWEEN LOCATION QUOTIENTS ${ }^{a}$ AND FACTOR INTENSITIES OF MANUFACTURING SECTORS, 1940 and 1960}

A. Capital-labor ratios

static quotients

change in quotients

B. Technicians per 10,000 employees

static quotients

change in quotients

\begin{tabular}{lr}
\multicolumn{2}{c}{ Northeast } \\
1940 & 1960 \\
\hline-.23 & .37
\end{tabular}

.63

\begin{tabular}{rr}
\multicolumn{2}{c}{ São Paulo } \\
1940 & 1960 \\
\hline .16 & .03
\end{tabular}
.14

aLQ $\mathrm{ij}=$ state $\mathrm{j}$ employment in industry $\mathrm{i}$ Brazil employment in industry $i$

$.47^{*}$ $.65^{*}$

state $\mathbf{j}$ total employment $\overline{\text { Brazil total employment }}$

Sources:

Employment by skill level comes from Brasil, Censo Industrial, 1960, Tables 4, 6 and 17.

Capital-labor ratios are from a Brazilian input-output matrix, van Rijckeghem (1969).

Note, $\mathrm{n}=13$ in $1940, \mathrm{n}=20$ in 1960.

*Significant .10, one-tail

were higher in the Northeast than in São Paulo. Consequently, unskilled labor in both regions is in unlimited supply to manufacturers, at a salary which is thirty-three percent higher in São Paulo than in the Northeast. The fact that actual salaries in São Paulo for nominally unskilled labor were about 100 percent higher suggests that skill differences in the labor force are significant.

Baer and Herve (1966) argue that in developing countries, the availability of managerial and technical manpower is a significant factor in the choice of technique, which appears to be correct for high-technology Brazilian industry (Leff, 1968). Consequently, a more fruitful test of the Heckscher-Ohlin theorem would focus on skilled labor as a scarce factor (cf. Keesing, 1966; Kenen, 1970).

São Paulo has persistently exceeded the Northeast in levels of educational expenditure, school enrollment rates, school years completed, and literacy. In 1960, technician salaries were only six percent above the Brazilian average, while operative salaries were twenty-one percent above this average. The São Paulo ratio of technician: operative salaries, then was about fifteen percent lower than in Brazil as a whole, further confirming the state's skill abundance. The same indicators identify the Northeast as especially skill poor. ${ }^{4}$

The second hypothesis is that skill-intensive industries concentrate in São Paulo and avoid the Northeast. For each region, the skill-intensity of the various manufacturing industries is correlated with their corresponding location quotients. The national ratio of college-level technicians per 10,000 workers is the index of skill intensity used here. Conforming to expectation in both 1940 and 1960, the quotients for São Paulo are positively correlated with sectoral skill-intensities; for the Northeast, negatively correlated (Table 1, Panel B). 
TABLE 2

\section{PRODUCT-MOMENT CORRELATIONS OF LOCATION QUOTIENTS ${ }^{a}$} AND MAN-FARMLAND ENDOWMENTS

1940

A. Labor-intensive cotton

sugar

B. land-intensive

rice

corn

manioc

C. percent cropland

in beans and manioc

\footnotetext{
a. $\mathrm{LQij}=\frac{\text { state } \mathbf{j} \text { area in crop } \mathbf{i}}{\text { Brazil area in crop } \mathrm{i}} / \frac{\text { state } \mathbf{j} \text { total crop area }}{\text { Brazil total crop area }}$

b. factor endowment $j=$ labor $j$ / total farm land $j$

*significant, .05, one-tail, $\mathbf{n}=20$ states, excluding Guanabara

Sources: Brasil, Censo Agncola, 1940 and 1960.
}

A reasonable conclusion for the manufacturing sector is that institutional barriers, such as a minimum wage or an interest rate ceiling, by attenuating interregional factor price differences, reduce the impact of regional factor endowments. If such distortions did not exist in the Brazilian case, skilled labor might have less and unskilled labor more influence on regional specialization.

\section{Agriculture}

To the best of our knowledge, no one has tested the Heckscher-Ohlin theorem with respect to agricultural specialization. More so than in the industrial sector, natural resources (soils, climate) are a constraint on choice of activity; therefore, any test must be limited to ubiquitous crops. ${ }^{5}$ The third hypothesis is that regions specialize in those crops intensive in their abundant factors of production. Since little machinery has been traditionally used in Brazilian agriculture (Schuh, 1971), the land and labor intensity of ubiquitous crops seems most relevant. Although various estimates of factor intensity in Brazilian agriculture are not entirely consistent or credible, the following categorizations are compatible with cross-national analyses of production functions (Cline, 1970): cane and cotton, labor-intensive; rice, manioc, and corn, land-intensive.

Land endowment can be measured either by total area in farms or only area in crop. Since the Heckscher-Ohlin theorem requires that factor endowments be exogenous, and both land in farms and land in crops have been increasing in Brazil, there is no clear definition of this endowment. While the former includes land not even potentially arable, the latter is at best a minimum estimate of land endowment. Since crop land has been growing more rapidly than farm land, the latter is taken as a more reliable indicator. 
Specialization is expressed by a location quotient in which area is the unit of measurement. Since yields have not varied tremendously either cross-sectionally or secularly, area is a fairly good proxy for intended output. The numerator of the coefficient is the state's share of national area in a given crop; the denominator, the state's share of national cropland.

The location quotients for the five crops are correlated with labor-farmland endowments across states (Table 2, Panels A\&B). Conforming to hypothesis, labor-abundant states indeed seem to specialize in labor-intensive crops (cotton and sugar cane), while land-abundant states seem to specialize in rice, a landintensive crop. Land-abundant states, however, do not seem to specialize in corn and manioc, the other land-intensive crops. In fact, labor-abundant states seem to specialize in manioc.

The manioc paradox is resolvable by recalling that the Heckscher-Ohlin theorem is particularly applicable to tradable commodities. Myint (1958) argues that low-income rural populations are averse to risking their subsistence output for the production of crops with only commercial value. Where land is abundant, commercial output is expandible without reducing subsistence output, by the clearing of unused land and the expenditure of more effort. Consequently, the greater the land abundance, the smaller the share of total crop land in subsistence crops.

By virtue of their low value: weight ratios and cultural preferences, beans and manioc are Brazil's ubiquitous subsistence crops. The significantly positive correlation between shares of crop land devoted to these crops and man-farmland ratios lend some strength to a Myintian interpretation of the manioc paradox (Table 2, panel C). In other words, labor-abundant states tend to devote a large share of land to subsistence crops, some of which are land-intensive; however, the remaining land tends to be devoted to labor-intensive commercial crops, such as cotton and sugar cane.

The Heckscher-Ohlin theorem predicts that in the absence of trade, laborabundant regions will employ more labor-intensive techniques than land-abundant regions, ceteris paribus. If we heroically assume away interregional differences in production functions, tastes, natural resources, and capital endowments, then labor abundant regions should enjoy higher yields in all crops as a consequence of their labor-intensive techniques.

Interregional transport costs in Brazil have been declining rapidly in the last three decades, thereby facilitating trade. A by-product of trade should be the adoption of similar techniques everywhere, consequently reducing the correlation between yield and man-farmland ratios, the fourth hypothesis.

For five-year intervals during the period, 1931-1970, the yields of six ubiquitous crops are correlated with state man-farmland ratios. At least within the period, 1940-1960, interstate variations in man-farmland ratios have been fairly stable, which suggests that migration has not wiped out original differences in factor endowment ratios. Contrary to prediction, interstate variations in yields have not declined; moreover, the correlations between yields and man-farmland 
TABLE 3

STANDARD DEVIATIONS OF YIELDS AND THEIR CORRELATIONS WITH MAN-FARMLAND RATIOS, 1931-1970. ${ }^{a}$

\begin{tabular}{|c|c|c|c|c|c|c|c|c|c|}
\hline & & $\begin{array}{l}31 / \\
35\end{array}$ & $\begin{array}{l}1936 / \\
1940\end{array}$ & $\begin{array}{l}1941 / \\
1945\end{array}$ & $\begin{array}{l}1946 / \\
1950\end{array}$ & $\begin{array}{l}\text { 1951/ } \\
1955\end{array}$ & $\begin{array}{l}1956 / \\
1960\end{array}$ & $\begin{array}{l}1961 / \\
1965\end{array}$ & $\begin{array}{l}1966 / \\
1970\end{array}$ \\
\hline Cotton & $\begin{array}{l}\sigma \\
\mathrm{r}\end{array}$ & $\begin{array}{r}.065 \\
-.37\end{array}$ & $\begin{array}{r}.059 \\
-.16\end{array}$ & $\begin{array}{r}.065 \\
-.16\end{array}$ & $\begin{aligned} & .149 \\
- & .13\end{aligned}$ & $\begin{array}{r}.161 \\
-.42^{*}\end{array}$ & $\begin{aligned} & .142 \\
- & .14\end{aligned}$ & $\begin{array}{r}.212 \\
-.36\end{array}$ & $\begin{array}{r}.258 \\
-.30\end{array}$ \\
\hline Rice & & $\begin{array}{r}.080 \\
-.41\end{array}$ & $\begin{array}{r}.091 \\
-.26\end{array}$ & $\begin{array}{r}.129 \\
-.05\end{array}$ & $\begin{array}{l}.129 \\
.16\end{array}$ & $\begin{array}{l}.129 \\
.08\end{array}$ & $\begin{array}{l}.117 \\
.15\end{array}$ & $\begin{array}{l}.140 \\
.10\end{array}$ & $\begin{array}{l}.145 \\
.16\end{array}$ \\
\hline Cane & $\begin{array}{l}\sigma \\
\mathrm{r}\end{array}$ & $\begin{aligned} & .073 \\
- & .04\end{aligned}$ & $\begin{array}{l}.138 \\
.20\end{array}$ & $\begin{array}{l}.124 \\
.18\end{array}$ & $\begin{array}{l}.129 \\
.26\end{array}$ & $\begin{array}{l}.153 \\
.13\end{array}$ & $\begin{array}{l}.148 \\
.20\end{array}$ & $\begin{array}{l}.139 \\
.21\end{array}$ & $\begin{array}{l}.150 \\
.24\end{array}$ \\
\hline Beans & & $\begin{array}{r}.042 \\
-.38\end{array}$ & $\begin{array}{r}.092 \\
-.58^{*}\end{array}$ & $\begin{array}{r}.088 \\
-.66^{*}\end{array}$ & $\begin{array}{r}.117 \\
-.43^{*}\end{array}$ & $\begin{array}{r}.152 \\
-.53^{*}\end{array}$ & $\begin{array}{r}.139 \\
-.55^{*}\end{array}$ & $\begin{array}{r}.141 \\
-.55^{*}\end{array}$ & $\begin{array}{r}.149 \\
-.54^{*}\end{array}$ \\
\hline Manioc & $\begin{array}{l}\sigma \\
\mathrm{r}\end{array}$ & $\begin{array}{r}.092 \\
-.52 *\end{array}$ & $\begin{array}{r}.130 \\
-.40 *\end{array}$ & $\begin{array}{r}.113 \\
-.54 *\end{array}$ & $\begin{aligned} & .111 \\
- & .35\end{aligned}$ & $\begin{array}{r}.122 \\
-.31\end{array}$ & $\begin{array}{r}.137 \\
-.34\end{array}$ & $\begin{array}{r}.137 \\
-.37\end{array}$ & $\begin{array}{r}.132 \\
-.43^{*}\end{array}$ \\
\hline Corn & & $\begin{array}{r}.076 \\
-.49 *\end{array}$ & $\begin{array}{r}.092 \\
-.56^{*}\end{array}$ & $\begin{array}{r}.097 \\
-.54 *\end{array}$ & $\begin{aligned} & .131 \\
- & .38\end{aligned}$ & $\begin{aligned} & .212 \\
- & .24\end{aligned}$ & $\begin{array}{r}.172 \\
-.36\end{array}$ & $\begin{array}{r}.162 \\
-.45^{*}\end{array}$ & $\begin{aligned} & .173 \\
- & .36\end{aligned}$ \\
\hline Man-Farmland ${ }^{b}$ & & & $\sigma$ & & & 47 & & 04 & \\
\hline
\end{tabular}

(a) All variables expressed in logarithms, since from the Cobb-Douglas production function $Q / \mathrm{T}=$
$(\mathrm{N} / \mathrm{T})^{\propto}$, where $\propto$ is the output elasticity of labor.

(b) Man-land ratios used in correlations are available only for census years. 1940 factor endowments are correlated with yields for 1931-1945, 1950 endowments, for 1946-1955; and 1960 endowments, for 19561970.

* significant at .10 level (two-tail), $\mathrm{n}=20$ states.

Sources: Output and acreage are collected by Servico de Estatistica de Producão, Ministerio de Agricultura, and published in Brasil, Anuario Estatistica, various years. Farm labor force and area are from Brasil, Censo Agricola, 1940, 1950, and 1960. Labor force data for 1950 are the least reliable.

ratios have not become less positive; i.e., converged toward zero. On the contrary, more often than not these correlations have been negative, except for sugar cane and rice in recent quinquennia (Table 3).

Why are the yield predictions so far off the mark? The answer lies in an appreciation of the history of Brazilian frontier settlement. As a relatively landsurplus economy, Brazil has tended to expand its agricultural production by the incorporation of new lands which has been facilitated by a continual improvement and extension in the transportation network and by considerable migration. As soils in the older, more densely populated zones are "mined," virgin soils of high natural fertility are brought into production. Contrary to our initial assumption, then, there are significant interstate fertility differences that are negatively correlated with rural population densities.

\section{CONCLUSIONS}

Regional tests of the Heckscher-Ohlin theorem have been proposed to circumvent the problems of differences in production functions that obscure international tests. As has been shown by the original Leontieff paradox, by the regional 
tests of Moroney-Walker and Estle, and by the present evidence, prior specification of the relevant factor endowments is difficult. In the Brazilian context, industrial labor legislation effectively distorts wage signals from the more labor abundant region. In the agricultural sector, frontier expansion and associated interregional fertility differentials hinder the measurement of land endowments. The positive conclusions are that: 1) the abundance of skilled labor influences regional manufacturing patterns, and 2) the man-farmland endowment influences specialization in commercial crops, both in the expected direction.

\section{FOOTNOTES}

1. Brasil, Censo Industrial, 1960, Table 1; Brasil, Censo de Servicos, 1950, "Fercado de Credito." In São Paulo, interest on deposits was $4.4 \%$, while Recife and Salvador, the rates were 4.7 and 5.1 percent respectively. Note that interest rates do not adequately reflect capital scarcity since usury laws were in force.

2. Anuario Estatistico do Brasil, 1960.

3. Pesquisa Nacional de Amostragem Domiciliar, various quarters, surveys earnings, unemployment, etc. of urban and rural households in several regions of Brazil.

4. Brasil, Censo Industrial, 1960, various state volumes.

5. See Brasil, Ministerio de Planejamento, Programa Estrategico de Desenvolvimento, 1968-1970. Estudo Especial, Zoneamento Agricola e Pecuario do Brasil (February 1969), on suitability of different regions for various crops.

\section{REFERENCES}

Baer, Wener and Herve, Michel, 1966. "Employment and Industrialiation in Underdeveloped Countries." QJE, February.

Cline, William R., 1970. The Economic Consequences of a Land Reform in Brasil. Amersterdam: North Holland.

Davis, Lance E., 1963. "The Investment Market, 1870-1914; The Evolution of a National Market," J. Econ. Hist., September.

Estle, Edwin, 1967. "A More Conclusive Regional Test of the Heckscher-Ohlin Hypothesis." JPE, December.

Harris, John R, and Todaro, Michael, 1970. "Migration and Unemployment." AER, March.

Keesing, Donald B., 1966, "Labor Skills and Comparative Advantage". AER, May.

Kenen, Peter, 1970, "Skills, Human Capital, and Comparative Advantage". In: Education, Income, and Human Capital, edited by W. Lee Hansen, New York: N.B.E.R.

Kravis, Irving, 1956. "Availability and Other Influences on the Commodity Composition of Trade". JPE, April.

Leff, Nathaniel, 1968, The Brazilian Capital Goods Industry, 1929-1964. Cambridge, Mass.: Harvard University.

Leontieff, Wassily, 1966. "Domestic Production and Foreign Trade: The American Capital Position ReExamined." Input-Output Economics. Oxford University Press, Chapter 5.

Moroney, John R. and Walker, James M., 1966. "A Regional Test of the Heckscher-Ohlin hypothesis". JPE, December.

Moroney, J.R., 1970. "Factor Prices, Fector Prices, and Regional Factor Endowments. JPE, January/ February.

Myint, Hla, 1958, “The 'Classical Theory' of International Trade and the Undeveloped Countries," Econ. J., June.

Ohlin, Bertel, 1933. Interregional and International Trade, Cambridge, Mass.: Harvard.

Romans, J. Thomas, 1965. Capital Exports and Growth Among U. S. Regions. Middleton, Connecticut: Wesleyan University Press.

Rijckeghem, Willy van., 1969. "An Intersectoral Consistency Model for Economic Planning in Brazil." In The Economy of Brazil, edited by Howard S. Ellis. Berkeley: University of California.

Schaaf, A.A., 1966. "Regional Differences in Mortgage Financing Costs." J. Finance, March.

Schuh, G. Edward, 1971. The Agricultural Development of Brazil. New York, Praeger.

Todaro, Michael, 1969. "A Model of Labor Migration”. AER, March.

Vanek, Jaroslav, 1963. The Natural Resource Content of U.S. Foreign Trade, 1870-1955. Cambridge, Mass.: M.I.T. Press. 